\title{
Farm Household Livelihood Strategies in Intermediate Zone of Jammu and Kashmir
}

\author{
Naseem A. Qammer ${ }^{1}$, Farhet A. Shaheen ${ }^{1 *}$, Shabir A. Wani ${ }^{1}$, Nageena Nazir ${ }^{2}$, \\ Farooq A. Lone ${ }^{3}$ and Shamim A. Simnanis ${ }^{4}$ \\ ${ }^{1}$ School of Agricultural Economics and Horti-Business Management (SAE\&HB), ${ }^{2}$ Division of \\ Agricultural statistics, ${ }^{3}$ Division of Environmental sciences, ${ }^{4}$ Division of Fruit Science \\ SKUAST-Kashmir, Shalimar, India \\ *Corresponding author
}

\section{A B S T R A C T}

This study is undertaken in inter-mediate hill agro-ecological zone of Jammu and Kashmir to identify the different livelihood strategies adopted by the household and what are the factors which are responsible for adopting of these livelihood strategies. A total of 251 tribal hill farmers were surveyed from Rajouri and Poonch districts comprising of 25

Keywords

Livelihood strategies, Ordinal logistic regression, Inter-mediate hill zone, J\&K

Article Info

Accepted: 20 January 2021 Available Online: 10 February 2021 villages drawn from 4 blocks representing lower, mid and high altitude villages. The study uses Sustainability Livelihood Framework approach, descriptive analysis and ordinal logistic regression model. Results revealed that only 31 per cent of households' income comes from agriculture and rest $(69 \%)$ comes from off-form sources for their livelihoods. The estimates of family size, no. of workers, household education, house value, fixed assets, loan and urgent need non-farm work show negative and significant relation with dependent variable (dependence on agriculture) indicating that with the increase in the value of these explanatory variables their dependence on agriculture reduces. Due to low income from agriculture and allied activities, households are diversifying more towards the off-farm sources of income. Government through development departments and research stations should make proper efforts in providing proper technical knowhow and latest farming methods and input technologies in order to boost the efficiency and productivity which has remained confined to plains only. Building of social overheads and increased investment in mountainous region apart from proper training through skill development programmes should be provided so that these mountainous people can augment their income by employing in different agriculture and allied income generating activities.

\section{Introduction}

Livelihood strategies are defined as those activities adopted by households to provide a means of living. According to The Department for International Development's (DFID) sustainable livelihoods glossary the term livelihood strategies denotes: "the range and combination of activities and choices that people make in order to achieve their livelihood goals". There is diversity in livelihoods at every level, for example, members of a household may work in different places engaging in various activities, 
either temporarily or permanently. Individuals themselves may rely on a range of different income-generating activities at the same time (DFID 2001). Due to the increased importance of off-farm income in household livelihoods, livelihood diversification has generally occurred. Livelihood strategies consist of how people engage in and combine different income generating activities, how they use different resources and how much these resources influence household livelihood strategies. In the livelihoods approach, resources are referred to as 'assets' or 'capitals'. The things people doing for their living are referred to as 'livelihood activities' in a livelihood framework (DFID 1999). This framework divides livelihood assets into five types, (i) Human assets: skills, education, health, age etc. (ii) Natural assets: land, water, trees etc. (iii) Physical assets: produced investment goods. (iv) Financial assets: borrow, loan access and (v) Social assets: networks and associations (Chen et al., 2013; Li et al., 2014, Hua et al., 2017 and Shaheen et al., 2017). Different studies showed that roughly more than 50 per cent of rural household incomes in low income countries are generated from engagement in non-farm activities This has been verified by recent studies in Africa (Ellis and Freeman, 2004), as well as past evidence from Africa and Asia (Reardon, 1997). A strong positive correlation between the proportion of household income obtained from non-farm sources and overall household income has been observed in numerous studies (Adams and $\mathrm{He}, 1995$; Barrett et al., 2001; Ellis and Freeman, 2004). The increase in off-farm employment is the most effective way for poverty alleviation and increased income of households (Barrett et al., 2001; Lanjouw and Feder, 2001; Haggblade et al., 2002; De Janvry et al., 2005; World Bank, 2009; Haggblade et al., 2010; Jacquelyn, 2010). Increase in off-farm income will be more remunerative to build up the financial, social, human and physical assets to make them less dependent on farm livelihoods. It also indicates that more educated and healthier population are able to diversify into non-farm livelihood activities. In general, livelihood assets play a dominant role in the transformation of livelihood strategies (Bryceson, 1996). Besides sticking with agricultural operations, human assets drive households to non-agricultural employment (Reenberg et al., 2013). Owing to the inaccessibility, fragile ecosystem, marginality, poor and remote community characteristics of mountainous areas, there are limited livelihood capitals and livelihood strategies for the tribal communities living in such areas. So it is important to study the extent to which household in study area (intermediate zone of $\mathrm{J} \& \mathrm{~K}$ ) depend on agriculture and their diversification towards off-farm sources for livelihood. It is in this context that 'farm household livelihood strategies in inter-mediate zone of Jammu and Kashmir' was undertaken to analyse the various issues of livelihood among tribal farm households in hilly areas.

\section{Materials and Methods}

Jammu and Kashmir is a mountainous union territory and occupies a central position in the continent of Asia. Out of 3.5 million ha of mountainous area of India, nearly two -third i.e, 2.3 million ha are found exclusively in Jammu and Kashmir. Rajouri and Poonch are the two important mountainous districts which fall in intermediate agro-climatic zone. Inter-mediate zone is transition between subtropical and temperate comprises of the mid and high altitude areas of the Panjal trap having altitude range from 800-1500 m masl. The zone is characterized by monsoon, concentration of precipitation, relatively wetter, cold winters and higher mean annual rainfall than subtropical zone. The people living in hilly areas of Rajouri and Poonch districts are of different ethnic groups, caste 
and culture. People speak Pahari and Kashmiri language except of Gujjars and Bakarwals who speak Gogri. Most of the household (98\%) rear livestock like buffalo, sheep and goats, poultry etc. Households inhabited in upper reaches of mountains have kaccha houses with almost poor quality of electricity, water and toilet facilities. Agriculture is substantially more important to households living on mountains than the people living in urban areas. In the study area, it was observed that about 60 per cent of household belong to marginal farm category and about 40 per cent to small farm category. Agriculture along with livestock rearing is only the farming system as has been adopted by the household in the study area.

\section{The design of the dependent variable}

In order to estimate the dependency level of farm household on agriculture, aggregate household income and factors responsible for their diversification we designed the dependent variable and various independent variables.

\section{A. Income sources}

Mainly there are two sources of farm household's income i.e agriculture and allied activities and off-farm sources. For designing the dependent variable, we calculate farm household's net income, agriculture net income and off-farm net income. Agriculture net income was calculated by subtracting the cost of inputs used in the production process, such as seed and starter animals, fodder, fertilizer, pesticides, livestock medicine, and so on from the gross income from crops, livestock, calculated by multiplying crop yields, livestock yields, by the unit price prevailing in the market during the investigation year. Off-farm net income was calculated by adding family members' income from labour, including wages and business, employment, pensions and then by subtracting it by the total household expenditure.

\section{Share of agriculture net income}

The share of agriculture net income to total household net income was calculated for each household and used to group sample households into four classes according to the share of net income from agriculture, and thus dependence on agriculture interpreted in terms of livelihood strategies (LS): LS 1, $<20 \%=$ less dependent; LS 2, 20\%-40\%, = moderately dependent; LS 3, 40\%-60\%, = highly dependent; and LS $4>60 \%$, = extremely dependent (Xu et al., 2015)

\section{The design of the independent variables}

In order to better understand how people develop and maintain their livelihoods, the UK Department for International Development (DFID), building on the work of practitioners and academics, developed the Sustainable Livelihoods Framework (SLF). This framework is an analytical tool, useful for understanding the many factors that affect a person's livelihood and how those factors interact with each other. The SLF views livelihoods as system and provides a way to understand (i) the assets people draw upon (ii) the strategies they draw to make a living (iii) the context within which a livelihood is developed and (iv) the factors that make a livelihood more or less vulnerable and unsustainable.

Using the Sustainable Livelihood Framework as a base, the factors affecting farmer's choices of livelihood strategies were divided into five types of capital: human, physical, natural, financial, and social (Table 1). The different explanatory variables used in the model were also used in previous studies as determinants of livelihood strategies by 
various researcher (Abdulai and Crole Rees, 2001; De Janvry and Sadoulet, 2001; Escobal, 2001; Schwarze and Zeller, 2005; Croppenstedt, 2006; Rahut and Micevska Scharf, 2012; Agyeman et al., 2014; Yenesew et al., 2015; Khatiwada et al., 2017; Makate and Mango, 2017, Shaheen, et al., 2017).

To identify the drivers and their effect on livelihood strategies, we used Ordinal Logistic Regression analysis. The logistic regression techniques are powerful in analyzing livelihood choices and their determinants given their suitability for modelling categorical dependent variables (Babulo et al., 2008; Mutenje et al., 2010; Rahut and Micevska Scharf, 2012; Walelign, 2016; Khatiwada et al., 2017; Makate and Mango, 2017; Negeri and Demissie, 2017; Bealu, 2019; Dedehouanou and Mcpeak, 2019)

The dependent variable is divided into four categories i.e., LS1, LS2, LS3 and LS4. As described earlier since our dependent variable (dependence on agriculture) is categorical we used ordinal logistic regression for our analysis.

\section{Results and Discussion}

The analysis revealed that household in the study area are found to be more dependent on off-farm activities than on farm activities and get their income from self-employed businesses, wage work, and other nonagricultural livelihood activities to maintain their household livelihoods. The analysis of livelihood strategies revealed that on an average 31 per cent of farm household income come from agriculture activities and about 69 per cent come from off-farm activities. It was observed that households in study area were merely dependent on agriculture and more on off-farm activities for their livelihood (Table 2). The findings further revealed that households were dependent on more than one source of income for their living and these results were consistent with the findings of De Janvry and Sadoulet, (2001) where they found that off-farm activities generate on an average more than half of farm household income than from agriculture and allied activities.

\section{Drivers of livelihood strategies}

Table 3 indicates the mean and standard deviation of the five capital assets used in livelihood strategies model. Average family size was 5.22 which ranged from 4.18 to 5.38 from the farm household livelihood strategies class LS4 to LS1. Average number of workers was found out to be 1.38. As the family size increases, the average number of worker also increases which means that with increase in family size the burden on family head/ elder members increase to earn more for their family means. Average number of children up to 15 years range from 0.25 to 0.43 (from LS4 to LS1). Household head education's years was found to be lower in LS4 and average number of years was found out to be more in LS1. Average age of the household head shows increasing trend as it move from LS1 to LS4 indicating that with ageing, household heads become more dependent on agriculture activities than those who are young.

Natural capital: We have included two variables in natural capital (i) Per capita cultivated area and (ii) Standard Animal Unit (SAU), to determine the level of dependency of household on agriculture. The household who have more per capita area are more dependent on agriculture and vice versa. Almost all of the households have livestock in study area. Majority of the people are rearing them for milk, curd, ghee, meat, wool etc. So the households who have more land holding prefer to rare more livestock, because of availability of fodder for livestock and FYM for their crops which is freely available for 
them. So, the household with more livestock and holding size are more dependent on agriculture for their livelihoods.

Physical capital: Value of house and fixed asset calculated at market prices were two variables considered under physical capital. Households who are more dependent on agriculture have less valuable house and fixed asset and vice versa, which indicates that households with more off-farm income are better-off than agricultural based household.

Financial capital: Loan from any financial institution and borrowings from relatives, friends etc were assessed and result show that household head who are more educated as well as government employees can easily avail loan facilities. On the other hand, household heads with less education go for borrowing from friends, relatives etc to combat their misery as well as rely more on agriculture.

Social capital: It was assessed by household's social network with friends, relatives, neighbours etc. Results reveal that household with more social network or relation are mostly dependent on agriculture and seek help from friends and relatives when they are in urgent need of money and the household who are less dependent on agriculture have more social network to get help from in finding and providing work or other assistance.

Table.1 Explanatory variables and their definitions

\begin{tabular}{|c|c|}
\hline Variable & Definition \\
\hline \multicolumn{2}{|c|}{ Human capital } \\
\hline family size & number of persons in household \\
\hline worker & number of laborers in household \\
\hline children & whether the household has children aged $5-15$ years old $(1=$ yes; $0=$ no $)$ \\
\hline househage & age of household head in years \\
\hline househedu & years of education of household head \\
\hline \multicolumn{2}{|c|}{ Physical capital } \\
\hline asset val & current market value of all the fixed assets that a household possesses (Rs) \\
\hline House val & current market value of the value of the house(s) that a household possesses (Rs) \\
\hline \multicolumn{2}{|c|}{ Natural capital } \\
\hline area & household's per capita area of cultivated land (kanal) \\
\hline SAU & $\begin{array}{l}\text { Standard animal unit (Buffalo, Cow, Bullock Horse }=1, \text { Calf }=0.50 \text {, Sheep and } \\
\text { goat }=0.20 \text { ) }\end{array}$ \\
\hline \multicolumn{2}{|c|}{ Financial capital } \\
\hline loan & $\begin{array}{l}\text { whether the household loaned from formal financial channels (such as banks) in the past } \\
\text { five years }(1=\text { yes; } 0=\text { no) }\end{array}$ \\
\hline borrow & $\begin{array}{l}\text { whether the household borrowed from relatives and friends in the past five years }(1= \\
\text { yes; } 0=\text { no) }\end{array}$ \\
\hline \multicolumn{2}{|c|}{ Social capital } \\
\hline socnetmo & $\begin{array}{l}\text { the social network of relatives and friends available for assistance when in urgent need } \\
\text { of money ( } 1=\text { none; } 2=\text { underdeveloped; } 3=\text { developed) }\end{array}$ \\
\hline socnetfwo & $\begin{array}{l}\text { the social network of relatives and friends available for assistance when seeking non- } \\
\text { farm work }(1=\text { none; } 2=\text { underdeveloped; } 3=\text { developed })\end{array}$ \\
\hline
\end{tabular}


Table.2 Livelihood strategies and income diversification table

\begin{tabular}{|c|c|c|c|c|c|c|c|c|}
\hline \multirow[b]{2}{*}{$\begin{array}{c}\text { LS } \\
\text { Class }\end{array}$} & \multirow[b]{2}{*}{$\begin{array}{l}\text { Agriculture } \\
\text { income Share }\end{array}$} & \multirow[b]{2}{*}{$\begin{array}{c}\text { Dependence on } \\
\text { agriculture income }\end{array}$} & \multirow[b]{2}{*}{$\begin{array}{c}\text { No. of } \\
\text { household }\end{array}$} & \multirow[b]{2}{*}{ Percentage } & \multicolumn{2}{|c|}{$\begin{array}{l}\text { Average income share } \\
(\%)\end{array}$} & \multicolumn{2}{|c|}{$\begin{array}{l}\text { Net household income } \\
\text { from all source in Rs. }\end{array}$} \\
\hline & & & & & Agriculture & $\begin{array}{l}\text { Off -farm } \\
\text { income }\end{array}$ & Mean & Range \\
\hline 1 & below $20 \%$ & Less dependent & 142 & 56.57 & 12 & 88 & 48,648 & $\begin{array}{l}11,314- \\
1,50,821\end{array}$ \\
\hline 2 & $21-40 \%$ & $\begin{array}{c}\text { Moderately } \\
\text { dependent }\end{array}$ & 58 & 23.11 & 29 & 71 & 28,881 & $9,060-64,279$ \\
\hline 3 & $41-60 \%$ & Highly dependent & 20 & 7.97 & .5 & 5 & 19,936 & $7,938-36,514$ \\
\hline 4 & above 60 & $\begin{array}{l}\text { Extremely } \\
\text { dependent }\end{array}$ & 31 & 12.35 & 60 & 40 & 16,644 & $1,056-35,445$ \\
\hline & & & 251 & & 31 & 69 & $1,14,111$ & \\
\hline
\end{tabular}

Table.3 Descriptive statistics for the independent variables

\begin{tabular}{|l|c|c|c|c|c|c|c|c|c|c|}
\hline Variable & LS1 & & LS2 & & LS3 & & LS4 & & Average & \\
\cline { 2 - 11 } & Mean & SD & Mean & SD & Mean & SD & Mean & SD & Mean & SD \\
\hline Family size (No.) & 5.38 & 1.28 & 5.32 & 1.17 & 4.90 & 1.19 & 4.18 & 1.10 & 5.22 & 1.18 \\
\hline Number of worker & 1.63 & 0.25 & 1.58 & 0.20 & 1.29 & 0.05 & 1.18 & 0.06 & 1.38 & 0.64 \\
\hline Children (No.) & 0.43 & 0.04 & 0.38 & 0.09 & 0.52 & 0.05 & 0.25 & 0.09 & 0.42 & 0.09 \\
\hline Hh edu (years) & 7.96 & 1.06 & 7.41 & 1.17 & 6.95 & 1.31 & 5.94 & 0.57 & 7.60 & 1.95 \\
\hline HhAge (years) & 43.77 & 10.42 & 45.93 & 10.21 & 55.01 & 11.99 & 52.01 & 11.55 & 44.75 & 10.85 \\
\hline Area (kanal) & 1.39 & 0.87 & 1.64 & 0.46 & 1.89 & 0.95 & 2.00 & 0.96 & 1.52 & 0.17 \\
\hline SAU & 2.45 & 1.44 & 2.72 & 1.43 & 2.96 & 2.25 & 3.01 & 2.41 & 2.91 & 2.19 \\
\hline In(house value) in Rs. & 1.97 & 0.78 & 1.92 & 0.78 & 1.55 & 0.67 & 1.20 & 0.59 & 1.89 & 0.78 \\
\hline In(fixed asset) in Rs. & 0.84 & 0.17 & 0.61 & 0.15 & 0.51 & 0.09 & 0.47 & 0.02 & 0.66 & 0.08 \\
\hline Loan(\%) & 0.20 & 0.08 & 0.17 & 0.06 & 0.16 & 0.05 & 0.03 & 0.01 & 0.07 & 0.03 \\
\hline Borrow(\%) & 0.56 & 0.01 & 0.68 & 0.09 & 0.48 & 0.05 & 0.70 & 0.09 & 0.59 & 0.09 \\
\hline socnetmo & 1.60 & 0.89 & 1.91 & 0.43 & 2.03 & 0.41 & 2.25 & 0.36 & 1.78 & 0.46 \\
\hline Socnetfwo & 2.58 & 0.99 & 2.13 & 1.9 & 2.14 & 1.12 & 1.83 & 1.15 & 2.02 & 1.09 \\
\hline
\end{tabular}

Table.4 Ordinal logistic regression estimates for the agriculture dependence model

\begin{tabular}{|l|c|c|}
\hline Explanatory variable & Regression coefficient & Std. error \\
\hline Family size & -0.424 & $0.173^{*}$ \\
\hline No. of worker & -3.462 & $0.545^{* *}$ \\
\hline children & -0.564 & 0.397 \\
\hline Hhedu & -0.340 & $0.050^{*}$ \\
\hline HhAge & 0.036 & $0.018^{*}$ \\
\hline Area & 0.711 & $0.019^{*}$ \\
\hline SAU & 0.528 & $0.013^{*}$ \\
\hline In(housevalue) & -0.019 & $0.002^{* *}$ \\
\hline In(fixedasset) & -0.103 & $0.005^{* *}$ \\
\hline Loan & -0.831 & $0.011^{*}$ \\
\hline Borrow & 0.576 & $0.0387^{*}$ \\
\hline socnetmo & 0.107 & $0.025^{*}$ \\
\hline Socnetnfwo & -1.253 & $0.353^{*}$ \\
\hline
\end{tabular}

Note: No. of observation $=251$, Wald $\mathrm{Chi}^{2}(14)=187.556$; Prob $>\mathrm{chi}^{2}=0.0000$;

Pseudo $\mathrm{R}^{2}=0.660 *$ and $* *$ denote significance at 5 and 1 per cent probability level 


\section{Determinants of livelihood strategies}

The results of ordinal logistic regression analysis depicted in Table 4 reveal that the value of wald chi $^{2}$ is 187.57 with probability greater than chi ${ }^{2}$ which is equal to 0.0000 . (prob $>\mathrm{chi}^{2}=0.000$ ) thus giving best fit to the model and also indicate that at least any one of the independent variable chosen for analysis has a significant effect on dependent variable. Furthermore, the value of pseudo $\mathrm{R}^{2}$ (0.66) also depicts goodness of fit. The model results reveal that as family size increases, dependence on agriculture is reduced by 0.42 times which confer that family size affects negatively the choice of livelihood strategies which make them to lean more towards offfarm strategies in order to meet the basic need of family like food, clothes, education, medical facilities etc. This finding is similar to that of Bezemer and Lerman (2002) which stated that larger households are more at risk of poverty and diversify more towards offfarm sources of income. The estimate of number of workers also show negative influence on dependent variable and is highly significant. This is due to the reason that as the family size increases the financial burden on household members also increase. In order to cope up with this, they usually go for offfarm activities which provide them cash income for the survival. Moreover, majority of the households keep their crop and livestock products for their household consumption like rice, corn flour, milk, ghee, fodder for feeding their livestock etc., which hinders in getting cash income flow. Household education was found to effect negatively due to fact that more educated heads are either employed in government jobs or in some kind of business activities that provide more income than agriculture. Age of family head was found to have positive effect on households' livelihood strategies (dependence on agriculture) which indicate that farmer's participation in off-farm activities decline as their age go up. The possible reason is that farmers, whose age is relatively younger, leaving other factors constant, could be pushed to engage more in off -farm activities than agriculture. Moreover, younger generation is more attracted towards off-farm income activities. Results show consistency with Barrett and Clay (2003) in which they found that households with young family members diversify more towards non-farm sector because of taking care of farming and household responsibilities. On the other hand elder farmers are well established and more experienced in agricultural activities, more resistant to new ideas and information; they are more likely to be set in their ways and may not venture into new diversification activities. Findings were in conformity with Asfir (2016) where he observed that age effect negatively to decision to diversify livelihood strategies to off-farm source. The per capita land owned by the household has a positive and significant relation with the dependent variable which indicates that households with more land are more oriented towards agriculture rather than diversifying their livelihood strategies towards off-farm activities. Livestock holding (SAU) had a positive and significant relation with dependence on agriculture which connotes that households with more dependence on agriculture do hold more number of livestock to meet the family and farm needs. The result is consistent with the findings of. Household owning more livestock are oriented more towards on-farm livelihood strategies than off-farm livelihood (Barrett et al., 2005 and Jansen et al., 2006). Furthermore, it was observed that likelihood of diversify livelihood into off-farm activities decrease by 1.9 per cent for household with more livestock number as they are interested more toward on-farm activities than off-farm source of income (Eneyew and Bekele, 2012). 
House value: As the value of the house and fixed assets increase, their dependence on agriculture reduces. Increased value of house implies that they are more dependent on offfarm income and less on-farm income which is due to the reason that houses have become a symbol of wealth in the society and with more off-farm income means some portion of it is used for construction of attractive houses in order to maintain their standard of living and social status. Findings are similar with $\mathrm{Xu}$ et al., (2015) wherein he found that as the house value increases, households dependence on agriculture reduced by 1.7 times.

Financial capital: Loans were found to have a negative influence on livelihood strategies which is probably due to the reason that educated households with government jobs are availing more loan facilities from financial institution. On the other hand, households who are likely to borrow from informal sources, they are more dependent on agriculture as it is difficult for them to avail loan from formal institution.

Social capital: Social network of relatives and friends available for assistance when in urgent need of money had a positive influence on livelihood strategies which means that households who are more dependent on agriculture have more strong network of relatives and friend when in urgent need of money. Xu et al., (2015) also observed that household with highly developed social network when in urgent need of money were 2.81 times more dependent on agriculture than those with no or very less social network. Influence of social network of relatives and friends available for assistance when seeking non-farm work had negative influence and is highly significant. Zhao et al., (2003) revealed that more than 75 per cent of the households were assisted by the relatives and friends in seeking non-farm work when they tend to diversify more toward off-source of income.

In conclusion and recommendations the present study analyzed various livelihood strategies adopted by the household in the study area and found that there are two main source of household's income i.e., (i) income generated from crops and livestock activities and (ii) off-farm income where households are dependent on private small scale businesses, public/private sector services, daily wage labourers, skilled and semi-skilled work etc. The average income of the households was found to be Rs. 1,14,111 per annum out of which contribution of off-farm was about 69 per cent and rest $(31 \%)$ was from the farm activities. About 57 per cent of households fall in category of less dependent on agriculture, moderately dependent (23\%), extremely dependent (12\%) and highly dependent $(8 \%)$ on agriculture for their livelihood. The study concludes that agriculture merely is not an enough source of income for the household livelihoods of intermediate hill zone so family members go for off-farm activities for their survival. The findings also show that household with more off-farm income have better living standard than those who are more dependent on agriculture. The main reason for giving more preference to off-farm activity is that agriculture remains neither more remunerative nor attractive and rather provides less incentive to farmer after toiling heavily which is not sufficient for their survival.

The households who are living in hilly areas or on high altitudes are not only producer but they are also labourer and consumer so there should be implementation of improved, innovative technology and development of such project that can enhance the agricultural productivity. Various skill development training programme, non-formal education 
system should be initiated that provide adequate training to individuals across gender and age groups so that it could help them to involve more in different type of productive and income augmenting activities.

There is huge potential for the horticultural crops in study area indicating that farmers/households should be encouraged by the concerned development departments to diversify their livelihood option to horticulture sector, particularly towards high value horticultural crops for better market returns.

Beautiful landscape with snow covered mountains and streams provide huge potential towards the establishment of tourism industry. Government should undertake various promotional activities related to tourism like transportation, resorts, hotels and restaurants etc. across inter-mediate hilly zone and historical Mughal road which can attract the tourists and by this way generate source of employment and income for the peoples of the region.

\section{References}

Abdulai, A. and A. Crole Rees (2001), "Determinants of income diversification amongst rural households in Southern Mali”, Food Policy, Vol.26, No.4, pp.437-452.

Agyeman, B.A.S., S. Asuming-Brempong and E.E. Onumah (2014), "Determinants of income diversification of farm households in the Western Region of Ghana", Quarterly Journal of International Agriculture, Vol.53, No.1, pp.55-72.

Adams, R.H. and J.J. He (1995), Sources of income inequality and poverty in rural Pakistan, Reserach report 102. Washingon D.C. International Food Research Institute (IFPRI).

Asfir, S.S. (2016), "Determinants of rural households livelihood strategies:
Evidence from Western Ethiopia”, Journal of Economics and Sustainable Development, Vol. 7, No. 15, pp.103.

Barrette, C.B., T. Reardon and P. Webb (2001), "Non-farm income diversification and household livelihood strategies in Rural Africa: Concept, dynamics and policy implications", Food Policy, Vol. 26, pp.315-331.

Barrett, C. and D. Clay (2003), "How accurate is food for work self targeting in the presence of imperfect factor markets? Evidence from Ethiopia", Journal of Development Studies, Vol.39, pp. 152180.

Barrett, C.B., M.B. Clark, D.C. Clay and T. Reardon (2005), "Heterogeneous constraints, incentives and income diversification strategies in rural Africa", Quarterly Journal of International Agriculture, Vol.44, pp.37-60.

Babulo, B., B. Muys, F. Nega, E. Tollens, J. Nyssen, J. Deckers and E. Mathijs (2008), "Household livelihood strategies and forest dependence in the highlands of Tigray, northern Ethiopia", Agricultural Systems, Vol.98, pp.147-155.

Bealu, T. (2019), "Analysis of livelihood diversification practice to promote rural households food security: The case of Hawassa Zuria district of Sidama Zone, Ethiopia", Journal of Development and Agricultural Economics, Vol.11, No.1, pp.1-8.

Bezemer, D.J. and Z. Lerman (2002), Rural livelihoods in Armenia, The Centre for Agricultural Economic Research, The Department of Agricultural Economics and Management, Discussion Paper 403.

Bryceson, D.F. (1996), "Deagrarianization and rural employment in Sub-Saharan Africa: A sectoral perspective", World Development, Vol.24, No.1, pp.97-111.

Chen, H., T. Zhu, M. Krott, J.F. Calvo, G.P. Shivakoti and M. Inoue (2013), "Measurement and evaluation of livelihood assets in sustainable forest commons governance", Land Use Policy, Vol.30, pp.908-914. 
Croppenstedt, A. (2006), Household income structure and determinants in rural Egypt, ESA Working Paper No. 06-02 from Agricultural and Development Economics, Division of the Food and Agricultural Organization of the United Nations (FAO-ESA).

Dedehouanou, F. and J.G. Mcpeak, (2019), "Diversify more or less? Household income generation strategies and food security in rural Nigeria", Journal of Development Studies, Vol.56, No.4, pp.118.

De Janvry, A. and E. Sadoulet (2001), "Income strategies among rural households in Mexico: The role of off-Farm activities", World Development, Vol.92, No.3, pp.467-480.

De Janvry, A., E. Sadoulet and N. Zhu (2005), "The role of non-farm incomes in reducing rural poverty and inequality in China", CUDARE working paper 100, Department of Agricultural and Resource Economics, UCB.

Department for International Development (DFID) (1999), Sustainable Livelihoods Guidance Sheets, London, UK.

Department for International Development (DFID) (2001), Sustainable Livelihoods Guidance Sheets. Electronic edition.

Ellis, F. and H.A. Freemen (2004), "Rural livelihoods and poverty reduction strategies in four African countries", Journal of Development Studies, Vol.40, No.4, pp.1-30.

Eneyew, A. and W. Bekele (2012), "Determinants of livelihood strategies in Wolaita, Southern Ethiopia”, Agriculture Research Review, Vol.1, pp.153-161.

Escobal, J. (2001), "The determinants of nonfarm income diversification in rural Peru", World Development," Vol.29, No.3, pp.497-508.

Hua, X., J. Yan and Y. L. Zhang (2017), "Evaluating the role of livelihood assets in suitable livelihood strategies: Protocol for anti-poverty policy in the Eastern Tibetan Plateau, China", Ecoligical Indicator, Vol.78, pp.62-74.
Haggblade, S., P. Hazell, and T. Reardon, (2010), "The rural non-farm economy: prospects for growth and poverty reduction", World Development, Vol.38, pp.1429-1441

Haggblade, S., P. Hazell and T. Reardon (2002), Strategies for stimulating poverty alleviating growth in the rural nonfarm economy in developing countries, EPTD discussion paper 92, World Bank, Washington, D.C.

Jacquelyn, C. (2010), "The place of pluri activity in Brazil's agrarian reform institutions", Journal of Rural Studies, Vol.26, pp.85-93.

Jansen, H.G., J. Pender, A. Damon, W. Wielemaker and R. Schipper (2006), "Policies for sustainable development in the hill side areas of Honduras: A quantitative livelihoods approach", Agricultural Economics, Vol.34, pp.141153.

Khatiwada, S.P., W. Deng, B. Paudel, J.R. Khatiwada, J. Zhang and Y. Su (2017), "Household livelihood strategies and implication for poverty reduction in rural areas of central Nepal", Sustainability, Vol.9, No.4, pp.1-20.

Lanjouw, P. and G. Feder (2001), Rural nonfarm activities and rural development: from experience towards strategy, rural development strategy, background paper Washington, DC. The World Bank.

Li, Z., J. Yan, X. Hua, L. Xin and X. Li (2014), "Factors influencing the cultivated land abandonment of households of different types: A case study of 12 typical villages in Chongqing Municipality", Geographical Research, Vol.33, pp.721734.

Mutenje, M.J., F. Ortmann, S.R.D. Ferrer and M.A.G. Darroch (2010), "Rural livelihood diversity to manage economic shocks: Evidence from south-east Zimbabwe", Agrekon Vol.49, No.3, pp.338 -350 .

Makate, C. and N. Mango (2017), "Diversity amongst farm households and achievements from multi-stakeholder 
innovation platform approach: Lessons from Balaka Malawi," Agriculture and Food Security, Vol.6, No.1, pp.1-15.

Negeri, B. and G. Demissie (2017), "Livelihood diversification: strategies, determinants and challenges for pastoral and agropastoral communities of Bale zone, Ethiopia", American Journal of Environmental and Geoscience, Vol.1, No.1, pp.19-28.

Rahut, D.B. and M. Micevska Scharf (2012), "Livelihood diversification strategies in the Himalayas", Australian Journal of Agricultural and Resource Economics,Vol.56, No. 4, pp.558-582.

Reardon, T. (1997), "Using evidence of household income diversification to inform study of the rural non-farm labour market in Africa", World Development, Vol.25, No.5, pp. 735-748.

Reenberg, A., I. Maman and P. Oksen (2013), "Twenty years of land use and livelihood changes in South-East Niger: Obsolete and short-sighted adaptation to climatic and demographic pressures", Journal of Arid Environment, Vol.94, pp.47-58.

Shaheen, F.A., S.A. Wani, S.H. Baba and F. Naqash, 2017. Disadvantaged mountain farmers of Gurez valley in Kashmir: Issues of livelihood, vulnerability, externality and sustainability. Indian Journal of Agricultural Economics, Vol.72, No.3, pp.456-474.

Schwarze, S. and M. Zeller (2005), "Income diversification of rural households in central Sulawesi, Indonesia", Quarterly Journal of International Agriculture, Vol.44, No.1, pp.61-73.

Walelign, S. Z. (2016), "Livelihood strategies, environmental dependency and rural poverty: The case of two villages in rural Mozambique", Environment, Development and Sustainability, Vol.18, No.2, pp.593-613.

World Bank, 2009. From poor areas to poor people. China's evolving poverty reduction agenda: An assessment of poverty and inequality in China. Poverty Reduction and Economic Management Department, World Bank, Washington, D.C.

Xu, D., J. Zhang, G. Rasul, S. Liu, F. Xie, M. Cao and E. Liu (2015), "Household livelihood strategies and dependence on agriculture in the mountainous settlements in the three gorges reservoir area, China", Sustainability, Vol.7, No.5, pp.4850.

Yenesew, S. Y., N.O. Eric and B. Fekadu (2015), "Determinants of livelihood diversification strategies: The case of smallholder rural farm households in Debre Elias Woreda, East Gojjam Zone, Ethiopia," African Journal of Agricultural Research, Vol.10, No.19, pp. 1998-2013.

Zhao, Y. (2003), "The role of migrant networks in labor migration: The case of China", Contemporary Economic Policy, Vol.21, pp.500-511.

\section{How to cite this article:}

Naseem A. Qammer, Farhet A. Shaheen, Shabir A. Wani, Nageena Nazir, Farooq A. Lone and Shamim A. Simnanis. 2021. Farm Household Livelihood Strategies in Intermediate Zone of Jammu and Kashmir. Int.J.Curr.Microbiol.App.Sci. 10(02): 2644-2654.

doi: https://doi.org/10.20546/ijcmas.2021.1002.290 